Check for updates

Cite this: RSC Adv., 2019, 9, 18815

\title{
A cobalt-doped iron oxide nanozyme as a highly active peroxidase for renal tumor catalytic therapy $\dagger$
}

\begin{abstract}
Yixuan Wang, (D) a Hongjun Li, ${ }^{* b}$ Lihua Guo, ${ }^{a}$ Qi Jiang ${ }^{a}$ and Feng Liu ${ }^{a}$
The $\mathrm{Fe}_{3} \mathrm{O}_{4}$ nanozyme, the first reported nanozyme with intrinsic peroxidase-like activity, has been successfully employed for various diagnostic applications. However, only a few studies have been reported on the therapeutic applications of the $\mathrm{Fe}_{3} \mathrm{O}_{4}$ nanozyme partly due to its low affinity to the substrate $\mathrm{H}_{2} \mathrm{O}_{2}$. Herein, we report a new strategy for improving the peroxidase-like activity and affinity of the $\mathrm{Fe}_{3} \mathrm{O}_{4}$ nanozyme to $\mathrm{H}_{2} \mathrm{O}_{2}$ to generate reactive oxygen species (ROS) for kidney tumor catalytic therapy. We showed that cobalt-doped $\mathrm{Fe}_{3} \mathrm{O}_{4}\left(\mathrm{Co}\left(\mathrm{Fe}_{3} \mathrm{O}_{4}\right)\right.$ nanozymes possessed stronger peroxidase activity and a 100-fold higher affinity to $\mathrm{H}_{2} \mathrm{O}_{2}$ than the $\mathrm{Fe}_{3} \mathrm{O}_{4}$ nanozymes. The lysosome localization properties of $\mathrm{Co}\left(\mathrm{Fe}_{3} \mathrm{O}_{4}\right.$ enable $\mathrm{Co}\left(\mathrm{Fe}_{3} \mathrm{O}_{4}\right.$ to catalyze the decomposition of $\mathrm{H}_{2} \mathrm{O}_{2}$ at ultralow doses for the generation of ROS bursts to effectively kill human renal tumor cells both in vitro and in vivo. Moreover, our study provides the first evidence that the $\mathrm{Co} a \mathrm{Fe}_{3} \mathrm{O}_{4}$ nanozyme is a powerful nanozyme for the generation of ROS bursts upon the addition of $\mathrm{H}_{2} \mathrm{O}_{2}$ at ultralow doses, presenting a potential novel avenue for tumor nanozyme catalytic therapy.
\end{abstract}

Received 22nd December 2018 Accepted 8th March 2019

DOI: $10.1039 / \mathrm{c} 8 \mathrm{ra} 05487 \mathrm{~h}$

rsc.li/rsc-advances
Recently, significant efforts have been made to explore the feasibility of application of nanozymes in in vivo clinical diagnosis and therapy. ${ }^{\mathbf{9} 15-18}$ As the first well-studied nanozyme, $\mathrm{Fe}_{3} \mathrm{O}_{4}$ nanozymes have already been evaluated in tumor catalytic therapy for catalyzing the decomposition of hydrogen peroxide to generate ROS. ${ }^{16,19,20}$ However, because of the low affinity of the $\mathrm{Fe}_{3} \mathrm{O}_{4}$ nanozymes to $\mathrm{H}_{2} \mathrm{O}_{2}, \mathrm{Fe}_{3} \mathrm{O}_{4}$ nanozyme-based catalytic therapy typically requires an additional high dose of $\mathrm{H}_{2} \mathrm{O}_{2}$ (approximately $10^{-3}$ to $10^{-4}$ $\mathrm{M}) \mathbf{1}^{\mathbf{1 9 , 2 0}}$ this makes this nanozyme-based catalytic tumor therapy strategy unviable for practical application.

Some heterogeneous oxide nanomaterials, such as $\mathrm{ZnFeO}_{3}{ }^{21}$ and $\mathrm{NiFeO}_{4}{ }^{22}$, formed by iron and other metals have been reported to exhibit enhanced peroxidase-like behavior; this indicates that transition metal doping of $\mathrm{Fe}_{3} \mathrm{O}_{4}$ nanozymes may be an effective way to improve the enzymatic activity of these nanoenzymes; ${ }^{23}$ interestingly, Chen et al. have reported that $\mathrm{Fe}-\mathrm{Co}$ bimetallic alloy nanoparticles also exhibit high peroxidase-like activity. ${ }^{24}$ Moreover, Vetr et al. have investigated the effect of transition metal (Co, Ni, and $\mathrm{Zn}$ ) doping on the catalytic performance of $\mathrm{Fe}_{3} \mathrm{O}_{4}$ nanozymes. They have demonstrated that $\mathrm{NiFe}_{2} \mathrm{O}_{4}$ and $\mathrm{ZnFe}_{2} \mathrm{O}_{4}$ NPs exhibit lower catalytic activity as compared to $\mathrm{CoFe}_{2} \mathrm{O}_{4} \mathrm{NPs}^{25}$ Thus, doping of cobalt, a non-noble metal, into $\mathrm{Fe}_{3} \mathrm{O}_{4}$ nanozymes is a promising method to improve the peroxidaselike activity of $\mathrm{Fe}_{3} \mathrm{O}_{4}$ nanozymes; however, all these studies focus on the in vitro biosensing applications of metal-doped $\mathrm{Fe}_{3} \mathrm{O}_{4}$ nanozymes, and the applications of these nanozymes in tumor catalytic therapy have not been explored.
${ }^{a}$ Department of Nephrology, China-Japan Union Hospital of Jilin University, Changchun, 130033, China

${ }^{b}$ The Examination Center, China-Japan Union Hospital of Jilin University, Changchun, 130033, China. E-mail: lihongjun1960@126.com

$\dagger$ Electronic supplementary information (ESI) available. See DOI: $10.1039 / \mathrm{c} 8 \mathrm{ra} 05487 \mathrm{~h}$ 
In this study, we demonstrated that doping of Co into $\mathrm{Fe}_{3} \mathrm{O}_{4}$ nanozymes $\left(\mathrm{Co} @ \mathrm{Fe}_{3} \mathrm{O}_{4}\right)$ resulted in not only excellent peroxidase-like activity, but also a 100 -fold higher affinity of $\mathrm{Co@} \mathrm{Fe}_{3} \mathrm{O}_{4}$ to $\mathrm{H}_{2} \mathrm{O}_{2}$ than that in the case of $\mathrm{Fe}_{3} \mathrm{O}_{4}$ nanozymes. By employing $\mathrm{Co@} \mathrm{Fe}_{3} \mathrm{O}_{4}$ nanozymes, we successfully achieved effective antitumor activity with the addition of an ultralow dose (10 nM) of $\mathrm{H}_{2} \mathrm{O}_{2}$ both in vitro and in vivo. This study provides a promising strategy to enhance the peroxidase-like activity of the $\mathrm{Fe}_{3} \mathrm{O}_{4}$ nanozyme and achieves the purpose of $\mathrm{Fe}_{3} \mathrm{O}_{4}$ nanozyme based-renal tumor catalytic therapy.

\section{Materials and methods}

\section{Materials}

Chemicals and materials were supplied by Sigma-Aldrich (St. Louis, MO) unless otherwise specified.

\section{Synthesis and characterization of the $\mathrm{Fe}_{3} \mathrm{O}_{4}$ and $\mathrm{Co@} \mathrm{Fe}_{3} \mathrm{O}_{4}$ nanozymes}

The $\mathrm{Fe}_{3} \mathrm{O}_{4}$ nanozymes and Co-doped $\mathrm{Fe}_{3} \mathrm{O}_{4}$ nanozymes were synthesized according to the solvothermal method reported in the literature $\mathbf{1 0 , 2 6}^{\mathbf{1 0}}$ with some modifications. Briefly, for the $\mathrm{Fe}_{3} \mathrm{O}_{4}$ nanozymes, $\mathrm{FeCl}_{3} \cdot 6 \mathrm{H}_{2} \mathrm{O}(0.82 \mathrm{~g})$ was dissolved in $40 \mathrm{~mL}$ ethylene glycol. When the solution became clear, NaAc $(3.6 \mathrm{~g})$ was added under continuous vigorous stirring for $30 \mathrm{~min}$. The mixture was sonicated for $10 \mathrm{~min}$, then transferred to a $50 \mathrm{~mL}$ Teflon-lined stainless-steel autoclave and reacted at $200{ }^{\circ} \mathrm{C}$ for $12 \mathrm{~h}$. After the reaction was completed, the autoclave was cooled down to room temperature. Then, the products obtained were washed several times with ethanol and dried at $60{ }^{\circ} \mathrm{C}$.

The Co@ $\mathrm{Fe}_{3} \mathrm{O}_{4}$ nanozymes were also synthesized using the same procedure but extra $\mathrm{Co}\left(\mathrm{NO}_{3}\right)_{3} \cdot 6 \mathrm{H}_{2} \mathrm{O}(0.82 \mathrm{~g})$ was added to the reaction system.

The morphology and structure of the $\mathrm{Fe}_{3} \mathrm{O}_{4}$ and $\mathrm{Co} @ \mathrm{Fe}_{3} \mathrm{O}_{4}$ nanozymes were characterized by transmission electron microscopy (TEM, JEOL JEM-1400 120 kV), scanning electron microscopy (SEM, Zeiss Supra55) and dynamic light scattering (DLS, DynaPro Titan). Energy dispersive X-ray spectroscopy (EDX) of the $\mathrm{Fe}_{3} \mathrm{O}_{4}$ and $\mathrm{Co@} \mathrm{Fe}_{3} \mathrm{O}_{4}$ nanozymes was conducted using the Tecnai G2 F30 instrument. X-ray diffraction (XRD) measurements were performed using the X'Pert pro Philips X-ray powder diffractometer. X-ray photoelectron spectroscopy (XPS) was performed by the ESCALab220i-XL high-performance electron spectrometer with a monochromatic $\mathrm{Al} \mathrm{K} \alpha$ source.

\section{Kinetic analysis of the $\mathrm{Fe}_{3} \mathrm{O}_{4}$ and $\mathrm{Co@Fe} \mathrm{O}_{4}$ nanozymes}

The kinetic parameters of the $\mathrm{Fe}_{3} \mathrm{O}_{4}$ and $\mathrm{Co} @ \mathrm{Fe}_{3} \mathrm{O}_{4}$ nanozymes were determined by monitoring the absorbance change at $652 \mathrm{~nm}$ using the iMark ${ }^{\mathrm{TM}}$ Microplate Reader (BioRad, USA) in the time course mode at room temperature. Kinetic assays were carried out using the $\mathrm{Fe}_{3} \mathrm{O}_{4}$ nanozymes $(0.2 \mu \mathrm{g})$ or $\mathrm{Co} @ \mathrm{Fe}_{3} \mathrm{O}_{4}$ nanozymes $(0.2 \mu \mathrm{g})$ in a $100 \mu \mathrm{L}$ of reaction buffer $(0.2 \mathrm{M}$ NaAc buffer, $\mathrm{pH} 4.5)$ in the presence of $\mathrm{H}_{2} \mathrm{O}_{2}$ and TMB. The kinetic analysis of $\mathrm{Fe}_{3} \mathrm{O}_{4}$ and $\mathrm{Co} @ \mathrm{Fe}_{3} \mathrm{O}_{4}$ with $\mathrm{H}_{2} \mathrm{O}_{2}$ as the substrate was performed by varying the concentrations of $\mathrm{H}_{2} \mathrm{O}_{2}$ with $0.8 \mathrm{mM}$ TMB and vice versa. The absorbance $(652 \mathrm{~nm})$ changes were calculated relative to the changes in the molar concentration of TMB using the molar absorption coefficient of $39000 \mathrm{M}^{-1} \mathrm{~cm}^{-1}$ for the TMBderived oxidation products according to the Beer-Lambert law. ${ }^{27}$ All the measurements were performed at least in triplicate, and the values were then averaged. The results are provided as mean \pm the standard deviation (SD). The Michaelis-Menten constant was calculated using the Lineweaver-Burk plots of the double reciprocal of the MichaelisMenten equation $\nu=V_{\max } \times[\mathrm{S}] /\left(K_{\mathrm{M}}+[\mathrm{S}]\right)$ by GraphPad Prism 6.02 (GraphPad Software), where $\nu$ is the initial velocity, $V_{\max }$ is the maximal reaction velocity, $[S]$ is the concentration of the substrate and $K_{\mathrm{M}}$ is the Michaelis-Menten constant.

\section{ESR spectroscopy measurements}

The ESR measurements were carried out using a Bruker electron spin resonance (ESR) spectrometer (A300-10/12, Germany) at ambient temperature. Herein, fifty microliter aliquots of the control or sample solutions were put in glass capillary tubes with the internal diameters of $1 \mathrm{~mm}$ and sealed. The capillary tubes were then inserted into the ESR cavity, and the spectra were obtained at selected times. The instrument settings are as follows: $1 \mathrm{G}$ field modulation, $100 \mathrm{G}$ scan range, and a $20 \mathrm{~mW}$ microwave power for the detection of spin adducts using spin traps. The spin trap BMPO was employed to verify the formation of hydroxyl radicals $\left(\mathrm{OH}^{*}\right)$ during the degradation of $\mathrm{H}_{2} \mathrm{O}_{2}$ in the presence of the $\mathrm{Fe}_{3} \mathrm{O}_{4}$ or $\mathrm{Co} @ \mathrm{Fe}_{3} \mathrm{O}_{4}$ nanozymes under the same conditions. The amount of hydroxyl radicals was quantitatively estimated by the ESR signal intensity of the hydroxyl radical spin adduct (BMPO/OH$\left.{ }^{*}\right)$ using the peak-to-peak height of the second line of the ESR spectrum.

\section{Cell viability assay}

The cytotoxicity of the $\mathrm{Fe}_{3} \mathrm{O}_{4}$ and $\mathrm{Co@Fe} \mathrm{O}_{4}$ nanozymes with the addition of $10 \mathrm{nM} \mathrm{H} \mathrm{H}_{2} \mathrm{O}_{2}$ was determined using the CCK-8 cell viability assay kit (Dojindo Molecular Technologies). Briefly, A-498 cells (Human renal cancer cell, ATCC, HTB-44) were plated in 96-well plates (BD Biosciences) with the density of $5 \times 10^{3}$ cells per well and cultured in $100 \mu \mathrm{L}$ EMEM (Catalog No. 30-2003) for 1 day before the addition of $\mathrm{Fe}_{3} \mathrm{O}_{4}, \mathrm{Co} @ \mathrm{Fe}_{3} \mathrm{O}_{4}$ nanozymes, or only the buffer as a control. On each plate, blank wells $(n=6)$ with media were defined as $0 \%$ viability. Moreover, the wells with only PBS-treated cells $(n=6)$ were defined as $100 \%$ viability. The dilutions of the $\mathrm{Fe}_{3} \mathrm{O}_{4}$ and $\mathrm{Co} @ \mathrm{Fe}_{3} \mathrm{O}_{4}$ nanozymes were prepared using a buffer containing $10 \mathrm{nM}$ $\mathrm{H}_{2} \mathrm{O}_{2}$. The cells were then exposed to the $\mathrm{Fe}_{3} \mathrm{O}_{4}$ or $\mathrm{Co} @ \mathrm{Fe}_{3} \mathrm{O}_{4}$ nanozymes at a series of concentrations (from 0 to $0.2 \mathrm{mg} \mathrm{mL}^{-1}$ ) for 24 hours. After stimulation, a $10 \mu \mathrm{L}$ CCK-8 solution was added to each well. The plates were then incubated for $4 \mathrm{~h}$ at $37{ }^{\circ} \mathrm{C}$. After this, the absorbance was determined at $450 \mathrm{~nm}$ using the Benchmark Plus microplate spectrophotometer (BioRad Laboratories, Inc.). The results presented herein are the average of those obtained via three independent experiments. 


\section{Localization of the $\mathrm{Fe}_{3} \mathrm{O}_{4}$ and $\mathrm{Co@} \mathrm{Fe}_{3} \mathrm{O}_{4}$ nanozymes in cytoplasm}

The cellular uptake and distribution of $\mathrm{Fe}_{3} \mathrm{O}_{4}$ or $\mathrm{Co} @ \mathrm{Fe}_{3} \mathrm{O}_{4}$ nanozymes in human renal tumor cells were investigated by a confocal laser scanning microscope. Briefly, the A-498 cells were plated on poly-L-lysine-treated coverslips (BD Biosciences) and cultured in a six-well plate (Corning) for $12 \mathrm{~h}$ before use. After stimulation for $48 \mathrm{~h}$ with the Alexa-488labeled $\mathrm{Fe}_{3} \mathrm{O}_{4}$ or $\mathrm{Co} @ \mathrm{Fe}_{3} \mathrm{O}_{4}$ nanozymes $\left(0.2 \mathrm{mg} \mathrm{mL} \mathrm{mL}^{-1}\right)$, the cells were washed with PBS, fixed in $4 \%$ cold formaldehyde in PBS for $5 \mathrm{~min}$, and then permeabilized with $0.1 \%$ Triton $\mathrm{X}$ 100. After being washed with PBS, the cells were blocked in a $5 \%$ normal goat serum for $30 \mathrm{~min}$ at room temperature. To visualize the lysosomes, the cells were incubated with antiLamp1 mAb (1:200, clone H4A3; Invitrogen) at $37{ }^{\circ} \mathrm{C}$ for $1 \mathrm{~h}$. The cells were then washed three times with PBS and incubated with goat anti-mouse IgG1 conjugated with Alexa555 (1: 500; Invitrogen) for $1 \mathrm{~h}$ at $37{ }^{\circ} \mathrm{C}$. Finally, the nuclei of the cells were stained with $4^{\prime}, 6^{\prime}$-diamidino-2-phenylindole (DAPI, $1 \mu \mathrm{g} \mathrm{mL}{ }^{-1}$, Roche Applied Science) for $10 \mathrm{~min}$ at room temperature. The samples were examined using a confocal laser scanning microscope (Olympus FluoView FV1000, Tokyo, Japan).

\section{Intracellular ROS assay}

The fluorescent probe $2^{\prime}, 7^{\prime}$-dichlorofluorescin diacetate $\left(\mathrm{H}_{2}\right.$ DCFDA, Sigma-Aldrich, D6883) was used to measure the intracellular generation of ROS by the $\mathrm{Fe}_{3} \mathrm{O}_{4}$ or $\mathrm{Co@} \mathrm{Fe}_{3} \mathrm{O}_{4}$ nanozymes. Briefly, the confluent A-498 cells on the coverslips (BD Biosciences) were incubated with $\mathrm{Fe}_{3} \mathrm{O}_{4}$ or $\mathrm{Co@} \mathrm{Fe}_{3} \mathrm{O}_{4}$ nanozymes $\left(0.2 \mathrm{mg} \mathrm{mL}^{-1}\right)$ for 4 hours. After being washed with PBS, the cells were incubated with $10 \mu \mathrm{M} \mathrm{H}_{2}$ DCFDA in a serumfree DMEM for $20 \mathrm{~min}$ at $37^{\circ} \mathrm{C}$ in the dark. The fluorescence intensities of $\mathrm{H}_{2}$ DCFDA were measured by a confocal laser scanning microscope (Olympus FluoView FV-1000, Tokyo, Japan).

\section{Apoptosis analysis}

The apoptosis analysis of the treated tumor cells was conducted by PI and annexin V staining and flow cytometry (FACSCaliburTM, Becton Dickinson, Franklin Lakes, NJ, USA). Briefly, the $\mathrm{Fe}_{3} \mathrm{O}_{4}$ and $\mathrm{Co@} \mathrm{Fe}_{3} \mathrm{O}_{4}\left(0.2 \mathrm{mg} \mathrm{mL} \mathrm{m}^{-1}\right)$ nanozymes were incubated with the A-498 tumor cell lines for $24 \mathrm{~h}$. After trypsinization, the treated A-498 tumor cells were incubated with annexin V and PI for 15 min to achieve nuclear staining. After this, the cells were fixed and incubated with streptavidin-fluorescein $\left(5 \mu \mathrm{g} \mathrm{mL}{ }^{-1}\right)$ (Sigma, USA) for $15 \mathrm{~min}$. Cell death was evaluated by the quantification of annexin-stained apoptotic cells and PI-stained necrotic cells using flow cytometry.

\section{Therapy studies}

Herein, eighteen female BALB/c nude mice bearing A-498 tumors were randomly assigned to four groups $(n=6$ mice per group). All the mice were intratumorally treated with a single dose of $\mathrm{Fe}_{3} \mathrm{O}_{4}$ and $\mathrm{Co@} \mathrm{Fe}_{3} \mathrm{O}_{4}$ nanozymes $\left(3 \mathrm{mg} \mathrm{mL}^{-1}\right.$,
$100 \mu \mathrm{L}$ ) with $10 \mathrm{nM} \mathrm{H} \mathrm{H}_{2} \mathrm{O}_{2}$ when the diameter of the tumors was about $100 \mathrm{~mm}^{3}$. For the controls, PBS was administered. The tumor size was measured 3 times a week. The tumor size was calculated as volume $\left[\mathrm{mm}^{3}\right]=$ length $\times$ width $^{2} \times \pi / 6$. The measured values are presented as mean \pm SD.

\section{Results}

\section{Characterization of the $\mathrm{Co@} \mathrm{Fe}_{3} \mathrm{O}_{4}$ nanozymes}

The $\mathrm{Fe}_{3} \mathrm{O}_{4}$ nanozymes and Co-doped $\mathrm{Fe}_{3} \mathrm{O}_{4}$ nanozymes ( $\mathrm{Co@} \mathrm{Fe}_{3} \mathrm{O}_{4}$ ) used in this study were synthesized by the solvothermal method. To study the composition of the asprepared nanozymes, the EDX analysis was performed. As shown in Fig. $\mathrm{S} 1, \uparrow$ the EDX spectrum of the $\mathrm{Co} @ \mathrm{Fe}_{3} \mathrm{O}_{4}$ nanozymes indicated that the $\mathrm{Fe}$ and Co elements were present in the nanoparticles. Based on the EDX mapping analysis, the content of $\mathrm{Fe}$ and $\mathrm{Co}$ in the $\mathrm{Co} @ \mathrm{Fe}_{3} \mathrm{O}_{4}$ nanozymes were determined as $33.48 \%$ and $16.23 \%$, respectively (Table S1 $\dagger$ ). In conclusion, herein, the synthesized $\mathrm{Co@} \mathrm{Fe}_{3} \mathrm{O}_{4}$ nanozymes contained $\mathrm{Fe}$ and $\mathrm{Co}$ with the ratio of approximately $2: 1$; this confirmed that Co was successfully doped into the $\mathrm{Fe}_{3} \mathrm{O}_{4}$ nanozymes by the simple solvothermal method.

To characterize the structure of the $\mathrm{Co} @ \mathrm{Fe}_{3} \mathrm{O}_{4}$ nanozymes, TEM, SEM, DLS and X-ray diffraction (XRD) analysis were performed. The TEM images of the as-prepared $\mathrm{Fe}_{3} \mathrm{O}_{4}$ and $\mathrm{Co@} \mathrm{Fe}_{3} \mathrm{O}_{4}$ nanozymes are shown in Fig. $1 \mathrm{~A}$ and $\mathrm{B}$, respectively. The SEM images of the $\mathrm{Fe}_{3} \mathrm{O}_{4}$ and $\mathrm{Co} @ \mathrm{Fe}_{3} \mathrm{O}_{4}$ nanozymes are presented in Fig. $\mathrm{S} 2 \mathrm{~A}$ and $\mathrm{B}, \uparrow$ respectively. The results indicate that the $\mathrm{Fe}_{3} \mathrm{O}_{4}$ and $\mathrm{Co@} \mathrm{Fe}_{3} \mathrm{O}_{4}$ nanozymes present a typical spherical morphology. The average size of the $\mathrm{Fe}_{3} \mathrm{O}_{4}$ nanozymes was determined to be $89.8 \pm$ $7.9 \mathrm{~nm}$ by the TEM images, whereas that of the $\mathrm{Co} @ \mathrm{Fe}_{3} \mathrm{O}_{4}$ nanozymes was determined to be $94.6 \pm 8.6 \mathrm{~nm}$. Moreover, the $\mathrm{Fe}_{3} \mathrm{O}_{4}$ and $\mathrm{Co} @ \mathrm{Fe}_{3} \mathrm{O}_{4}$ nanozymes exhibited the average size of $90.31 \pm 0.62 \mathrm{~nm}$ and $95.82 \pm 3.57 \mathrm{~nm}$ in solution (Fig. S2C and $\mathrm{D}_{\dagger} \dagger$ ), respectively. The XRD patterns of the asprepared nanozymes are shown in Fig. $1 \mathrm{C}$ and $\mathrm{D}$, which indicate that both the $\mathrm{Fe}_{3} \mathrm{O}_{4}$ and $\mathrm{Co@} \mathrm{Fe}_{3} \mathrm{O}_{4}$ nanozymes are well crystallized. Moreover, each characteristic diffraction peak of the $\mathrm{Co@} \mathrm{Fe}_{3} \mathrm{O}_{4}$ nanozymes was similar to that of the $\mathrm{Fe}_{3} \mathrm{O}_{4}$ nanozymes and the standard PDF card of $\mathrm{Fe}_{3} \mathrm{O}_{4}$ (JCPDS card no. 19-0629); this indicated that Co-doping of the $\mathrm{Fe}_{3} \mathrm{O}_{4}$ nanozymes did not affect the phase pattern of $\mathrm{Fe}_{3} \mathrm{O}_{4}$.

To characterize the oxidation state of cobalt in the

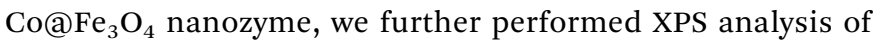
the as-prepared $\mathrm{Co} @ \mathrm{Fe}_{3} \mathrm{O}_{4}$ nanozyme. The high-resolution XPS spectrum of Co $2 \mathrm{p}$ is shown in Fig. 2A. The Co 2p XPS peak at $780.8 \mathrm{eV}$ was assigned to $\mathrm{Co}\left(2 \mathrm{p}_{3 / 2}\right)$, with a shake-up satellite peak at $785.9 \mathrm{eV}$. In addition, the Co 2p XPS peak at $797.2 \mathrm{eV}$ was attributed to $\mathrm{Co}\left(2 \mathrm{p}_{1 / 2}\right)$, with a satellite peak at $803.0 \mathrm{eV}^{28}$ These characteristic and satellites peaks confirm that $\mathrm{Co}^{2+}$ is present in the $\mathrm{Co@} \mathrm{Fe}_{3} \mathrm{O}_{4}$ nanozyme. Moreover, as shown in Fig. 2B, the Fe 2p XPS spectrum exhibited characteristic peaks with the binding energy values at 711.0 and $724.0 \mathrm{eV}$, assigned to the Fe $\left(2 \mathrm{p}_{3 / 2}\right)$ and $\mathrm{Fe}\left(2 \mathrm{p}_{1 / 2}\right)$ peaks, ${ }^{29}$ respectively. Since the atomic radius of iron $(140 \mathrm{pm})$ is 
A

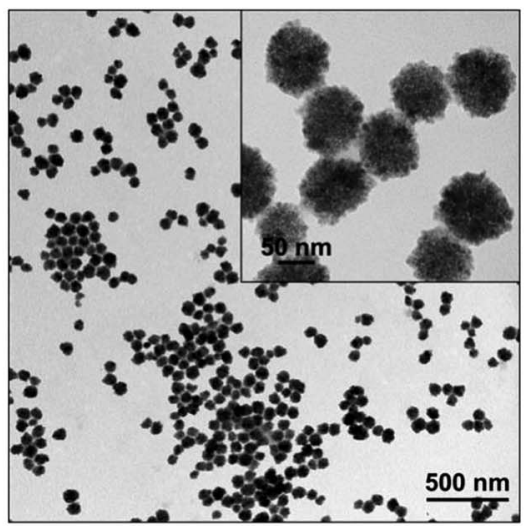

C

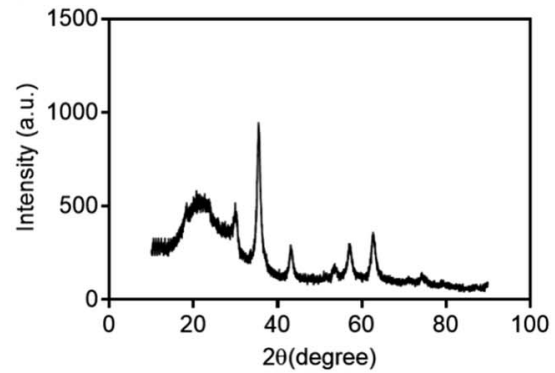

B

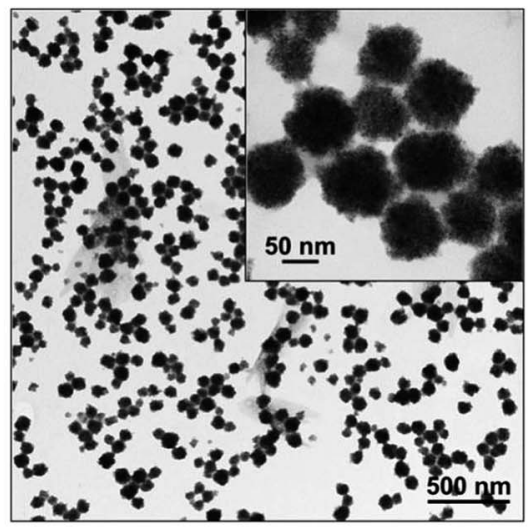

D

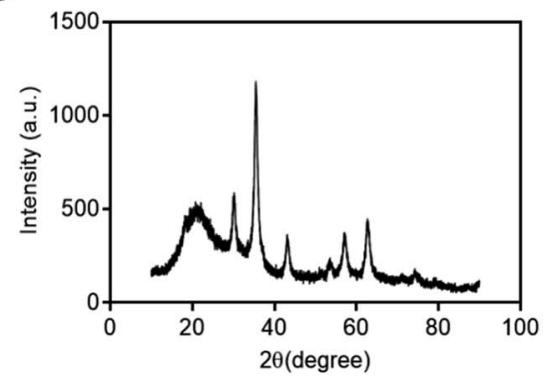

Fig. 1 TEM images and XRD diffraction patterns of the $\mathrm{Fe}_{3} \mathrm{O}_{4}(\mathrm{~A}$ and $\mathrm{C})$ and $\mathrm{Co}\left(\mathrm{Fe}_{3} \mathrm{O}_{4}\right.$ nanozymes (B and D), respectively.

A

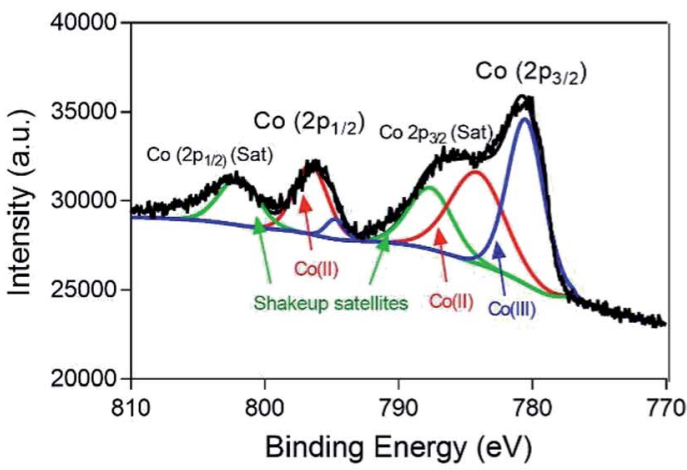

B

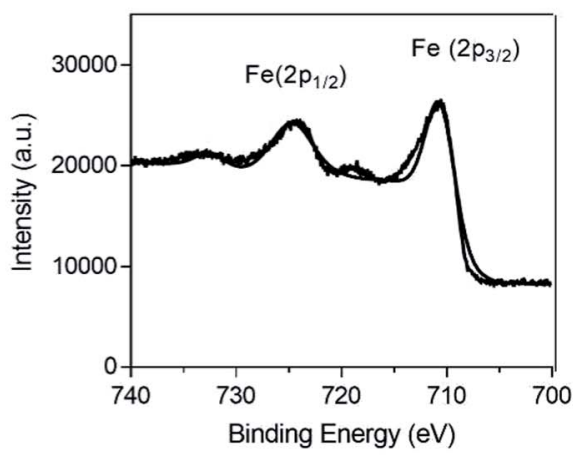

Fig. 2 XPS spectra of the Co@ $a \mathrm{Fe}_{3} \mathrm{O}_{4}$ nanozyme. (A) The Co $2 p$ XPS spectrum of the Co(aFe $\mathrm{O}_{4}$ nanozyme. (B) The Fe $2 p$ XPS spectrum of the $\mathrm{Co} \mathrm{Fe}_{3} \mathrm{O}_{4}$ nanozyme.

similar to that of the cobalt atom $(135 \mathrm{pm})$, these results suggest that the cobalt atoms are probably located only at the lattice positions of the $\mathrm{Fe}_{3} \mathrm{O}_{4}$ crystal structure.

Peroxidase-like activity and steady-state kinetic assay of the $\mathrm{Co@Fe}_{3} \mathrm{O}_{4}$ nanozymes

To directly compare the peroxidase-like activity of the $\mathrm{Fe}_{3} \mathrm{O}_{4}$ and $\mathrm{Co} @ \mathrm{Fe}_{3} \mathrm{O}_{4}$ nanozymes, we performed typical catalytic experiments using the peroxidase substrate $3,3^{\prime}, 5,5^{\prime}$-tetramethylbenzidine (TMB) and $\mathrm{H}_{2} \mathrm{O}_{2}$ as previously reported. ${ }^{11}$ The results showed that both the $\mathrm{Fe}_{3} \mathrm{O}_{4}$ and $\mathrm{Co@} \mathrm{Fe}_{3} \mathrm{O}_{4}$ nanozymes catalyzed the oxidation of TMB with $\mathrm{H}_{2} \mathrm{O}_{2}$ to produce blue color products with absorption at $652 \mathrm{~nm}$ (Fig. 3A). Moreover, the results demonstrated that the $\mathrm{Co} @ \mathrm{Fe}_{3} \mathrm{O}_{4}$ nanozymes exhibited a significant improvement in the peroxidase-like activity as compared to the $\mathrm{Fe}_{3} \mathrm{O}_{4}$ nanozymes; this indicated that a significant improvement in the nanozyme activity was achieved by Co doping of the $\mathrm{Fe}_{3} \mathrm{O}_{4}$ nanozymes.

The mechanism of action of the $\mathrm{Co}_{3} \mathrm{Fe}_{3} \mathrm{O}_{4}$ nanozymes was investigated using the ESR method. As shown in Fig. 3B, similar to the previously reported $\mathrm{Fe}_{3} \mathrm{O}_{4}$ nanozymes, the $\mathrm{Co} @ \mathrm{Fe}_{3} \mathrm{O}_{4}$ nanozymes significantly enhanced the generation 
A
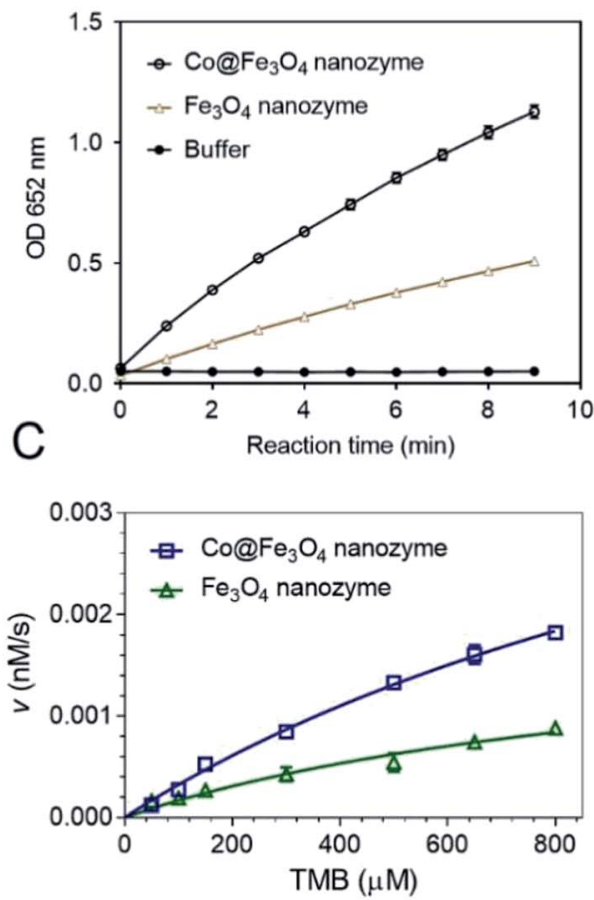

B

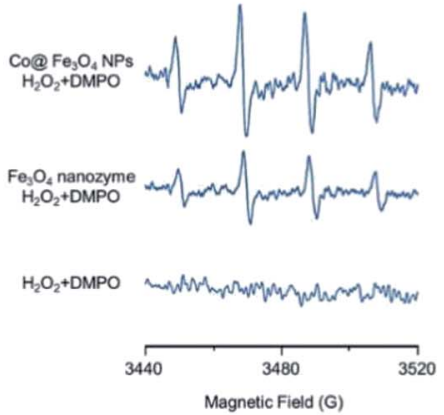

D

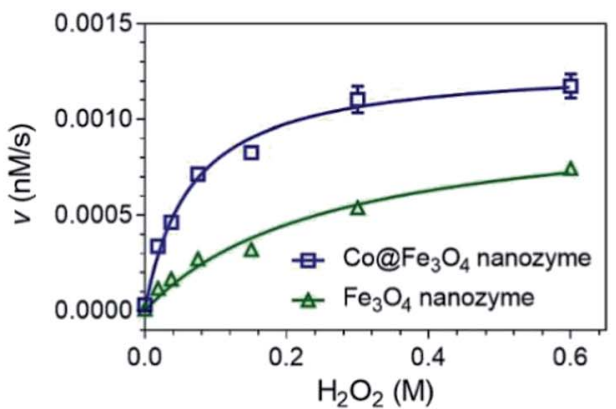

Fig. 3 Steady-state kinetic assay and the catalytic mechanism study for the $\mathrm{Fe}_{3} \mathrm{O}_{4}$ and $\mathrm{Co} O \mathrm{Fe}_{3} \mathrm{O}_{4}$ nanozymes. (A) Comparison between the peroxidase-like activities of the $\mathrm{Fe}_{3} \mathrm{O}_{4}$ and $\mathrm{Co} a \mathrm{Fe}_{3} \mathrm{O}_{4}$ nanozymes. (B) ESR detection of the hydroxyl radical generation during the catalytic reactions of the $\mathrm{Fe}_{3} \mathrm{O}_{4}$ and the $\mathrm{Co}\left(\mathrm{Fe}_{3} \mathrm{O}_{4}\right.$ nanozymes. (C-D) Kinetic assay of $\mathrm{Fe}_{3} \mathrm{O}_{4}$ and $\mathrm{Co}\left(\mathrm{Fe} \mathrm{O}_{3} \mathrm{O}_{4}\right.$ nanozymes with $\mathrm{TMB}$ (C) or $\mathrm{H}_{2} \mathrm{O}_{2}$ (D). For $\mathrm{C}$, the concentration of $\mathrm{H}_{2} \mathrm{O}_{2}$ was $100 \mathrm{mM}$, whereas the TMB concentration varied. For (D), the concentration of TMB was $0.8 \mathrm{mM}$, whereas the $\mathrm{H}_{2} \mathrm{O}_{2}$ concentration varied.

of hydroxyl radicals under acidic conditions. Importantly, the $\mathrm{Co} \mathrm{Fe}_{3} \mathrm{O}_{4}$ nanozymes generated more hydroxyl radicals than the $\mathrm{Fe}_{3} \mathrm{O}_{4}$ nanozymes under the same conditions; this further confirmed that Co doping significantly improved the peroxidase-like activity of the $\mathrm{Fe}_{3} \mathrm{O}_{4}$ nanozymes.

To obtain the apparent kinetic parameters of the $\mathrm{Co@Fe} \mathrm{O}_{4}$ nanozymes, the Michaelis-Menten experiments were performed. Fig. $3 \mathrm{C}$ and $\mathrm{D}$ show the typical kinetics for TMB and $\mathrm{H}_{2} \mathrm{O}_{2}$, respectively. The apparent Michaelis-Menten constant $\left(K_{\mathrm{M}}\right)$ and the maximum initial reaction rate $\left(V_{\max }\right)$ of the $\mathrm{Co} @ \mathrm{Fe}_{3} \mathrm{O}_{4}$ and $\mathrm{Fe}_{3} \mathrm{O}_{4}$ nanozymes were calculated. Moreover, these kinetic parameters of the $\mathrm{Co} @ \mathrm{Fe}_{3} \mathrm{O}_{4}$ nanozymes

Table 1 Comparison between the apparent Michaelis-Menten constants $\left(K_{M}\right)$ and maximum initial reaction rates $\left(V_{\max }\right)$ of the $\mathrm{Fe}_{3} \mathrm{O}_{4}$, $\mathrm{Co} a \mathrm{Fe}_{3} \mathrm{O}_{4}, \mathrm{CO}_{3} \mathrm{O}_{4}$ nanozymes and horseradish peroxidase (HRP) enzymes

\begin{tabular}{lrlllll}
\hline & & & & \multicolumn{2}{l}{$\begin{array}{l}V_{\max } \\
\left(10^{-8} \mathrm{M}^{-1} \mathrm{~s}^{-1}\right)\end{array}$} & \\
\cline { 2 - 3 } Nanozyme & \multicolumn{1}{c}{$\mathrm{H}_{2} \mathrm{O}_{2}(\mathrm{mM})$} & $\mathrm{TMB}$ & & $\mathrm{H}_{2} \mathrm{O}_{2}$ & $\mathrm{TMB}$ & References \\
\hline $\mathrm{Co@Fe}_{3} \mathrm{O}_{4}$ & 0.19 & 1.17 & & 71.5 & 37.9 & This work \\
$\mathrm{Fe}_{3} \mathrm{O}_{4}$ & 56.89 & 1.06 & & 59.6 & 16.8 & This work \\
$\mathrm{Co}_{3} \mathrm{O}_{4}$ & 1.14 & 5.09 & & 1.72 & 9.98 & 24 \\
$\mathrm{HRP}$ & 10.35 & 3.95 & & 0.689 & 37.65 & 11
\end{tabular}

were compared with those of the $\mathrm{Fe}_{3} \mathrm{O}_{4}$ and $\mathrm{Co}_{3} \mathrm{O}_{4}$ nanozymes and the natural enzyme HRP (Table 1). The $\mathrm{Fe}_{3} \mathrm{O}_{4}$ nanozymes typically exhibited low affinity to $\mathrm{H}_{2} \mathrm{O}_{2}$. The $K_{\mathrm{M}}$ value to $\mathrm{H}_{2} \mathrm{O}_{2}$ for the $\mathrm{Co} @ \mathrm{Fe}_{3} \mathrm{O}_{4}$ nanozymes was much lower than that for the $\mathrm{Fe}_{3} \mathrm{O}_{4}$ and $\mathrm{Co}_{3} \mathrm{O}_{4}$ nanozymes; this indicated that there was a significant improvement in the affinity of the nanozymes towards substrates after Co doping. More importantly, the $K_{\mathrm{M}}$ value to $\mathrm{H}_{2} \mathrm{O}_{2}$ for $\mathrm{Co} @ \mathrm{Fe}_{3} \mathrm{O}_{4}$ was nearly 50 -fold and 100-fold lower than that of the HRP enzyme and the $\mathrm{Fe}_{3} \mathrm{O}_{4}$ nanozymes, respectively; this demonstrated that the $\mathrm{Co} @ \mathrm{Fe}_{3} \mathrm{O}_{4}$ nanozymes exhibited much higher affinity to $\mathrm{H}_{2} \mathrm{O}_{2}$ than $\mathrm{HRP}$ and the other nanozymes. The $V_{\max }$ values to $\mathrm{H}_{2} \mathrm{O}_{2}$ for the $\mathrm{Co} @ \mathrm{Fe}_{3} \mathrm{O}_{4}$ nanozymes were also significantly improved.

\section{Anti-tumor activities and mechanistic study of the $\mathrm{Co@Fe}_{3} \mathrm{O}_{4}$ nanozymes}

Tumor cells typically possess higher levels of endogenous $\mathrm{H}_{2} \mathrm{O}_{2}$ and reactive oxygen species (ROS) than normal cells., ${ }^{\mathbf{9} 20}$ The balance of the ROS determines the fate of the tumor cells. It has been previously shown that stimulation of ROS is a common strategy for cancer chemotherapy. ${ }^{30,31}$ Thus, we employed the $\mathrm{Co} @ \mathrm{Fe}_{3} \mathrm{O}_{4}$ nanozymes to trigger the burst of ROS to kill the tumor cells.

$\mathrm{Fe}_{3} \mathrm{O}_{4}$ nanozymes, as the first well-studied nanozyme, have already been evaluated in tumor catalytic therapy for 
catalyzing the decomposition of hydrogen peroxide to generate ROS. ${ }^{19,20}$ However, because of the low affinity of these nanozymes to $\mathrm{H}_{2} \mathrm{O}_{2}$, the $\mathrm{Fe}_{3} \mathrm{O}_{4}$ nanozyme-based catalytic therapy typically requires additional high doses of $\mathrm{H}_{2} \mathrm{O}_{2}$ (approximately $10^{-3}$ to $\left.10^{-4} \mathrm{M}\right) ;^{19,20}$ this makes this nanozyme-based catalytic tumor therapy strategy unfeasible for practical application. In this study, we demonstrated that the $\mathrm{Co@} \mathrm{Fe}_{3} \mathrm{O}_{4}$ nanozymes exhibited a 100-fold higher affinity to $\mathrm{H}_{2} \mathrm{O}_{2}$ than the $\mathrm{Fe}_{3} \mathrm{O}_{4}$ nanozymes. Therefore, we next evaluated the catalytic antitumor activity of the $\mathrm{Co@} \mathrm{Fe}_{3} \mathrm{O}_{4}$ nanozymes with ultra-low doses of $\mathrm{H}_{2} \mathrm{O}_{2}$.

Considering that the typically used concentration of $\mathrm{H}_{2} \mathrm{O}_{2}$ is around $10^{-3}$ to $10^{-4} \mathrm{M}$, we have tried to use $10 \mathrm{nM}\left(10^{-8} \mathrm{M}\right)$ $\mathrm{H}_{2} \mathrm{O}_{2}$ to evaluate the antitumor activities of the $\mathrm{Co@} \mathrm{Fe}_{3} \mathrm{O}_{4}$ nanozymes. As shown in Fig. 4A, the buffer group containing $10 \mathrm{nM} \mathrm{H} \mathrm{H}_{2} \mathrm{O}_{2}$ exhibited no significant toxicity to kidney cancer cells; this indicated that the tumor cells were able to survive at $10 \mathrm{nM} \mathrm{H} \mathrm{H}_{2} \mathrm{O}_{2}$. After incubation with $0.2 \mathrm{mg} \mathrm{mL} \mathrm{mL}^{-1} \mathrm{Fe}_{3} \mathrm{O}_{4}$ nanozymes and $10 \mathrm{nM} \mathrm{H}_{2} \mathrm{O}_{2}$ for 24 hours, only less than $20 \%$ tumor cells were killed. These results are consistent with the previously reported results. Only a high dose of $\mathrm{H}_{2} \mathrm{O}_{2}$ allows the $\mathrm{Fe}_{3} \mathrm{O}_{4}$ nanozymes to effectively kill tumor cells. In the case of the $\mathrm{Co@} \mathrm{Fe}_{3} \mathrm{O}_{4}$ nanozymes, $0.02 \mathrm{mg} \mathrm{mL}^{-1} \mathrm{Co@} \mathrm{Fe}_{3} \mathrm{O}_{4}$

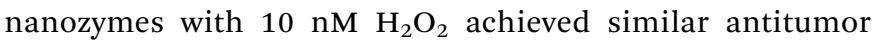
activities as $0.2 \mathrm{mg} \mathrm{mL}{ }^{-1} \mathrm{Fe}_{3} \mathrm{O}_{4}$ nanozymes. Moreover, $0.2 \mathrm{mg}$

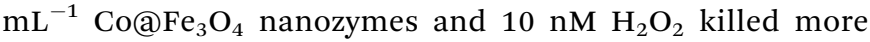
than $60 \%$ of the tumor cells within 24 hours. Thus, the $\mathrm{Co@} \mathrm{Fe}_{3} \mathrm{O}_{4}$ nanozymes effectively killed tumor cells with the addition of $\mathrm{H}_{2} \mathrm{O}_{2}$ at ultralow doses.

As is well-known, the $\mathrm{Fe}_{3} \mathrm{O}_{4}$ nanozymes exhibit peroxidase-like activity only under acidic conditions. ${ }^{12}$ Since the $\mathrm{Co@} \mathrm{Fe}_{3} \mathrm{O}_{4}$ nanozymes exhibit significant antitumor activity, we infer that the $\mathrm{Co@} \mathrm{Fe}_{3} \mathrm{O}_{4}$ nanozymes localize in the lysosome ( $\mathrm{pH} 4-5)$ after incubation with the tumor cells. To verify this hypothesis, we labeled the nanozymes with Alexa Fluor 488 to track their intracellular localization. As shown in Fig. 4B, we found that after incubation with tumor cells for 4 hours, most of the internalized $\mathrm{Fe}_{3} \mathrm{O}_{4}$ nanozymes co-localized with lysosomes. Similar to the $\mathrm{Fe}_{3} \mathrm{O}_{4}$ nanozymes, nearly all of the internalized $\mathrm{Co@} \mathrm{Fe}_{3} \mathrm{O}_{4}$ nanozymes localized in the lysosomes, the highly acidic microenvironment of which would favor the peroxidase-like activities. Thus, the colocalization analysis of the nanozymes and lysosomes demonstrated that the nanozyme-based tumor catalytic therapy strategy is feasible.

In our hypothesis, the antitumor activities of the $\mathrm{Co@} \mathrm{Fe}_{3} \mathrm{O}_{4}$ nanozymes are attributed to the catalytic generation of ROS by the decomposition of hydrogen peroxide, resulting in oxidative stress in the tumor cells. To verify this hypothesis, the intracellular ROS levels in the tumor cells

A
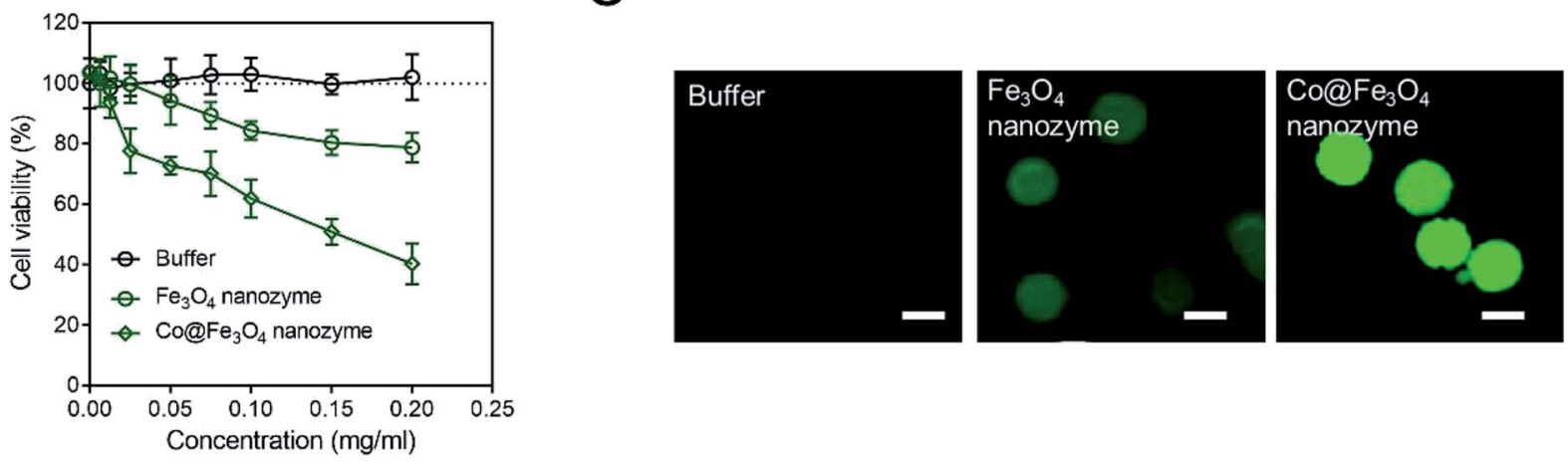
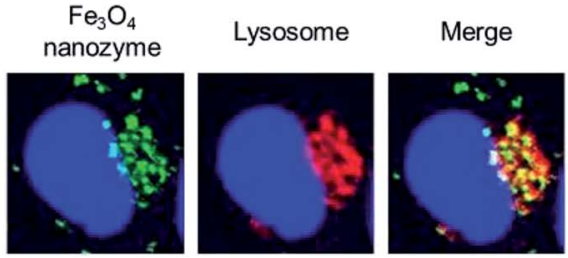

$\mathrm{Co@Fe} \mathrm{O}_{4}$ nanozyme

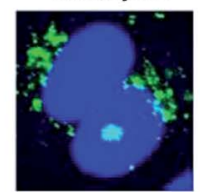

Merge

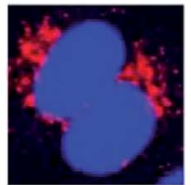

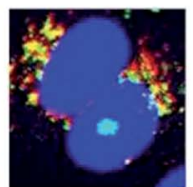
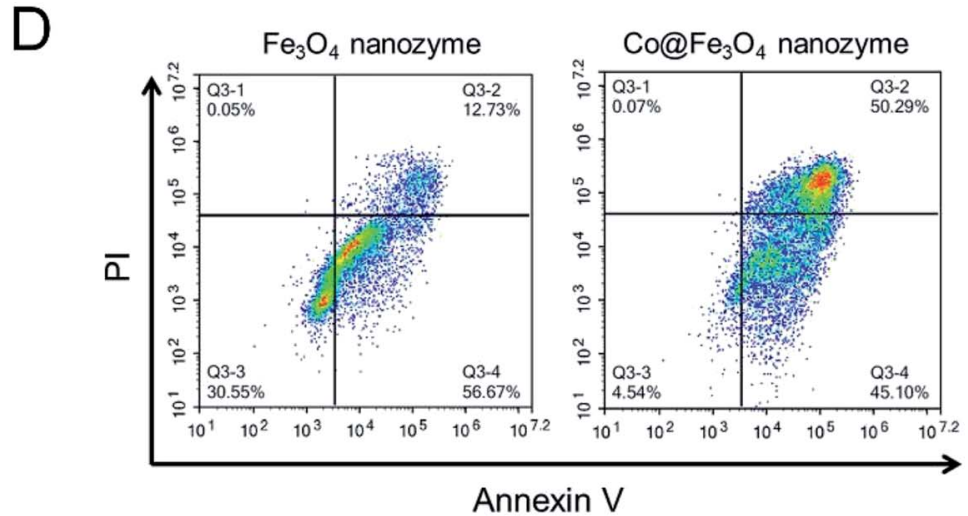

Annexin $\mathrm{V}$

Fig. 4 The antitumor cell activities and mechanistic study of the $\mathrm{Fe}_{3} \mathrm{O}_{4}$ and $\mathrm{Co} a \mathrm{Fe}_{3} \mathrm{O}_{4}$ nanozymes in vitro. (A) Cell viability of the human renal cancer cells A-498 incubated with the $\mathrm{Fe}_{3} \mathrm{O}_{4}$ and $\mathrm{Co} a \mathrm{Fe}_{3} \mathrm{O}_{4}$ nanozymes. The buffer contained $10 \mathrm{nM} \mathrm{H} \mathrm{H}_{2} \mathrm{O}_{2}$. (B) Localization of the Fe $3 \mathrm{O}_{4}$ and

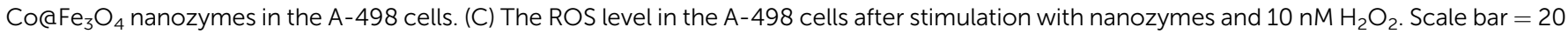
$\mu \mathrm{m}$. (D) Apoptosis analysis of the A-498 cells after incubation with nanozymes and $10 \mathrm{nM} \mathrm{H} \mathrm{H}_{2} \mathrm{O}_{2}$. 
were detected by employing $2^{\prime}, 7^{\prime}$-dichlorofluorescein diacetate ( $\mathrm{H}_{2}$ DCFDA), a typical ROS fluorescent dye. As shown in

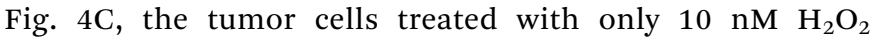
exhibited no significant ROS signal. After incubation with the $\mathrm{Fe}_{3} \mathrm{O}_{4}$ nanozymes and $10 \mathrm{nM} \mathrm{H} \mathrm{H}_{2} \mathrm{O}_{2}$, the green fluorescence intensity increased. In contrast, the tumor cells treated with the $\mathrm{Co} @ \mathrm{Fe}_{3} \mathrm{O}_{4}$ nanozymes and $10 \mathrm{nM} \mathrm{H}_{2} \mathrm{O}_{2}$ presented strong green fluorescence intensity, indicating that the $\mathrm{Co} @ \mathrm{Fe}_{3} \mathrm{O}_{4}$ nanozymes catalyzed the decomposition of $\mathrm{H}_{2} \mathrm{O}_{2}$ to generate an ROS burst to cause cell apoptosis. As shown in Fig. 4D, the tumor cells treated with the $\mathrm{Co@Fe} \mathrm{O}_{4}$ nanozymes and $10 \mathrm{nM} \mathrm{H}_{2} \mathrm{O}_{2}$ exhibited a significant apoptosis pattern. When the tumor cells were stimulated with the nanozymes at same concentration, the apoptosis induced by the $\mathrm{Co} @ \mathrm{Fe}_{3} \mathrm{O}_{4}$ nanozymes in the tumor cells was 4 -fold higher than that of the $\mathrm{Fe}_{3} \mathrm{O}_{4}$ nanozymes.

To further evaluate the antitumor activity of the $\mathrm{Co} @ \mathrm{Fe}_{3} \mathrm{O}_{4}$ nanozymes in vivo, we employed the human renal cancer cell A-498 xenograft in nude mice as a tumor model. The $\mathrm{Fe}_{3} \mathrm{O}_{4}$ nanozymes and $\mathrm{Co} @ \mathrm{Fe}_{3} \mathrm{O}_{4}$ nanozymes were intratumorally injected at the dose of $0.3 \mathrm{mg}$ in $100 \mu \mathrm{L}$ PBS and $10 \mathrm{nM} \mathrm{H}_{2} \mathrm{O}_{2}$ when the tumor volume reached $100 \mathrm{~mm}^{3}$. After this, the tumor volumes were determined 3 times a week. As shown in Fig. 5, the $\mathrm{Co} @ \mathrm{Fe}_{3} \mathrm{O}_{4}$ nanozyme-treated mice exhibited significant tumor inhibition after $\mathrm{Co} @ \mathrm{Fe}_{3} \mathrm{O}_{4}$ administration, whereas the $\mathrm{Fe}_{3} \mathrm{O}_{4}$ nanozyme-treated mice exhibited only slight tumor inhibition when compared with the PBS-treated mice. Thus, the $\mathrm{Co}_{0} \mathrm{Fe}_{3} \mathrm{O}_{4}$ nanozymes exhibited excellent in vivo renal tumor catalytic therapy activity, whereas the $\mathrm{Fe}_{3} \mathrm{O}_{4}$ nanozymes only partially inhibited the renal tumor growth due to their relative low peroxidase activity and low binding affinity to $\mathrm{H}_{2} \mathrm{O}_{2} ;{ }^{11}$ this was consistent with previous studies. ${ }^{9}$

Overall, these results provide strong evidence that the $\mathrm{Co@} \mathrm{Fe}_{3} \mathrm{O}_{4}$ nanozymes possess the ability to regulate intracellular ROS upon the addition of $\mathrm{H}_{2} \mathrm{O}_{2}$ at ultralow concentrations. Once located in the acidic microenvironment of lysosomes, these nanozymes induce cell death by boosting the level of ROS. The $\mathrm{Co} @ \mathrm{Fe}_{3} \mathrm{O}_{4}$ nanozymes exhibited significant antitumor activities against human renal tumor both in vitro and in vivo.

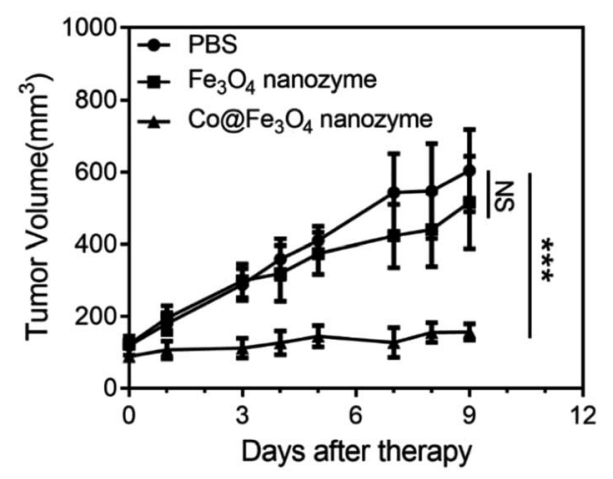

Fig. 5 Antitumor activities of the $\mathrm{Fe}_{3} \mathrm{O}_{4}$ and $\mathrm{Co}\left(\mathrm{Fe}_{3} \mathrm{O}_{4}\right.$ nanozymes in vivo. $n=6,{ }^{* * *} p<0.001$, NS, no significance, unpaired Student's $t$ test on day 9.

\section{Discussion and conclusion}

ROS-induced apoptosis is a popular strategy for cancer therapy. ${ }^{32-34}$ The tumor therapy strategies utilizing nanozymes mainly act by stimulating the production of ROS. ${ }^{9}$ The $\mathrm{Fe}_{3} \mathrm{O}_{4}$ nanozymes can simulate peroxidase and thereby efficiently catalyze the decomposition of $\mathrm{H}_{2} \mathrm{O}_{2}$ to generate ROS to inhibit tumors in vivo. However, the low binding affinity of the $\mathrm{Fe}_{3} \mathrm{O}_{4}$ nanozyme to $\mathrm{H}_{2} \mathrm{O}_{2}$ and its relatively low catalytic activity limit the development of the $\mathrm{Fe}_{3} \mathrm{O}_{4}$ nanozyme-based tumor catalytic therapy.

Transition metal doping has been demonstrated to be an effective and easy way to improve the peroxidase-like activity of $\mathrm{Fe}_{3} \mathrm{O}_{4}$ nanozymes. ${ }^{23}$ Among the transition metals, cobalt, a nonnoble metal, has been proven to be a promising dopant to enhance the enzymatic activity of the $\mathrm{Fe}_{3} \mathrm{O}_{4}$ nanozyme. ${ }^{25}$ Importantly, Chen et al. have systematically studied the effects of doping $\mathrm{Fe} / \mathrm{Co}$ at different ratios on the enzymatic activity of the $\mathrm{Fe}_{3} \mathrm{O}_{4}$ nanozyme. They have demonstrated that when the ratio of $\mathrm{Fe} / \mathrm{Co}$ is around $2: 1$, the peroxidase-like activity of the Co-doped $\mathrm{Fe}_{3} \mathrm{O}_{4}$ nanozyme is the best enzymatic activity. ${ }^{24}$ In this study, by employing a simple solvothermal method, we fabricated the $\mathrm{Co} @ \mathrm{Fe}_{3} \mathrm{O}_{4}$ nanozyme with the ratio of $\mathrm{Fe} / \mathrm{Co}$ around $2: 1$. Compared with the case of other strategies, including metal doping, biomimetic coating, and C-dot modification methods, that significantly improved the peroxidaselike activity of the $\mathrm{Fe}_{3} \mathrm{O}_{4}$ nanozyme, our $\mathrm{Co} @ \mathrm{Fe}_{3} \mathrm{O}_{4}$ nanozyme exhibited the best binding affinity to $\mathrm{H}_{2} \mathrm{O}_{2}$ (Table $\mathrm{S} 2 \dagger$ ).

The XPS and EDX analysis of the $\mathrm{Co}_{0} \mathrm{Fe}_{3} \mathrm{O}_{4}$ nanozyme demonstrated that the cobalt atoms were probably located only at the lattice positions of the $\mathrm{Fe}_{3} \mathrm{O}_{4}$ crystal structure. Although the Co atom possesses a similar size as the Fe atom, the Co atoms doped into the $\mathrm{Fe}_{3} \mathrm{O}_{4}$ crystal may still slightly change the surface physical environment, ${ }^{35}$ resulting in an improved binding affinity of the nanozyme to $\mathrm{H}_{2} \mathrm{O}_{2}$. In addition, the Co dopant may produce more catalytically active sites and substrate-binding sites on the surface of the $\mathrm{Co} @ \mathrm{Fe}_{3} \mathrm{O}_{4}$ nanozyme when compared with the case of the $\mathrm{Fe}_{3} \mathrm{O}_{4}$ nanozyme. ${ }^{36}$ Moreover, the higher redox potential of $\mathrm{Co}^{3+} / \mathrm{Co}^{2+}(1.30 \mathrm{~V})$ as compared to that of $\mathrm{Fe}^{3+} / \mathrm{Fe}^{2+}(0.771 \mathrm{~V})$ in the $\mathrm{Fe}_{3} \mathrm{O}_{4}$ nanozyme may be another reason for the improvement in the peroxidaselike activities of $\mathrm{Co} @ \mathrm{Fe}_{3} \mathrm{O}_{4} \cdot{ }^{37,38}$

In conclusion, using a simple solvothermal method, we successfully synthesized Co-doped $\mathrm{Fe}_{3} \mathrm{O}_{4}\left(\mathrm{Co} @ \mathrm{Fe}_{3} \mathrm{O}_{4}\right)$ nanozymes that contained $\mathrm{Fe}$ and $\mathrm{Co}$ at the ratio of approximately $2: 1$. The well-crystallized $\mathrm{Co} @ \mathrm{Fe}_{3} \mathrm{O}_{4}$ nanozymes exhibited excellent peroxidase-like activity. More importantly, Co doping makes the $\mathrm{Co} @ \mathrm{Fe}_{3} \mathrm{O}_{4}$ nanozymes exhibit a 50-fold and 100-fold higher affinity to $\mathrm{H}_{2} \mathrm{O}_{2}$ than that of the HRP and $\mathrm{Fe}_{3} \mathrm{O}_{4}$ nanozymes, respectively. The improvement of the $\mathrm{H}_{2} \mathrm{O}_{2}$ affinity renders the $\mathrm{Co@} \mathrm{Fe}_{3} \mathrm{O}_{4}$ nanozymes with excellent antitumor activity upon the addition of $\mathrm{H}_{2} \mathrm{O}_{2}$ at ultralow concentrations. When the $\mathrm{Co} @ \mathrm{Fe}_{3} \mathrm{O}_{4}$ nanozymes with enhanced peroxidase-like activities are specifically located in the acidic microenvironment of the lysosomes, they induce apoptosis of human renal tumor cells (A-498) by catalyzing the decomposition of $\mathrm{H}_{2} \mathrm{O}_{2}$ to 
generate an ROS burst. Importantly, the Co@ $\mathrm{Fe}_{3} \mathrm{O}_{4}$ nanozymes exhibited excellent antitumor activities both in vitro and in vivo for kidney tumor catalytic therapy.

\section{Conflicts of interest}

There are no conflicts to declare.

\section{References}

1 H. Wei and E. K. Wang, Chem. Soc. Rev., 2013, 42, 6060-6093. 2 Y. H. Lin, J. S. Ren and X. G. Qu, Acc. Chem. Res., 2014, 47, 1097-1105.

3 R. Ragg, M. N. Tahir and W. Tremel, Eur. J. Inorg. Chem., 2016, 1906-1915, DOI: 10.1002/ejic.201501237.

4 X. Y. Wang, Y. H. Hu and H. Wei, Inorg. Chem. Front., 2016, 3, 41-60.

5 H. Y. Shin, T. J. Park and M. I. Kim, J. Nanomater., 2015, 756278.

6 Z. Zhang, X. Zhang, B. Liu and J. Liu, J. Am. Chem. Soc., 2017, 139, 5412-5419.

7 B. W. Liu and J. W. Liu, Nano Res., 2017, 10, 1125-1148.

8 K. F. Xiangqin Meng, Prog. Biochem. Biophys., 2018, 45, 218236.

9 K. Fan, J. Xi, L. Fan, P. Wang, C. Zhu, Y. Tang, X. Xu, M. Liang, B. Jiang, X. Yan and L. Gao, Nat. Commun., 2018, 9, 1440.

10 L. Gao, J. Zhuang, L. Nie, J. Zhang, Y. Zhang, N. Gu, T. Wang, J. Feng, D. Yang, S. Perrett and X. Yan, Nat. Nanotechnol., 2007, 2, 577-583.

11 K. Fan, H. Wang, J. Xi, Q. Liu, X. Meng, D. Duan, L. Gao and X. Yan, Chem. Commun., 2017, 53, 424-427.

12 L. Gao, K. Fan and X. Yan, Theranostics, 2017, 7, 3207-3227. 13 J. Xie, G. Liu, H. S. Eden, H. Ai and X. Chen, Acc. Chem. Res., 2011, 44, 883-892.

14 K. Ulbrich, K. Hola, V. Subr, A. Bakandritsos, J. Tucek and R. Zboril, Chem. Rev., 2016, 116, 5338-5431.

15 L. L. Dugan, L. L. Tian, K. L. Quick, J. I. Hardt, M. Karimi, C. Brown, S. Loftin, H. Flores, S. M. Moerlein, J. Polich, S. D. Tabbal, J. W. Mink and J. S. Perlmutter, Ann. Neurol., 2014, 76, 393-402.

16 M. Huo, L. Wang, Y. Chen and J. Shi, Nat. Commun., 2017, 8, 357.

17 J. Yao, Y. Cheng, M. Zhou, S. Zhao, S. Lin, X. Wang, J. Wu, S. Li and H. Wei, Chem. Sci., 2018, 9, 2927-2933.

18 Y. Zhang, F. Wang, C. Liu, Z. Wang, L. Kang, Y. Huang, K. Dong, J. Ren and X. Qu, ACS Nano, 2018, 112(1), 651-661.
19 D. Zhang, Y. X. Zhao, Y. J. Gao, F. P. Gao, Y. S. Fan, X. J. Li, Z. Y. Duan and H. Wang, J. Mater. Chem. B, 2013, 1, 51005107.

20 S. Fu, S. Wang, X. Zhang, A. Qi, Z. Liu, X. Yu, C. Chen and L. Li, Colloids Surf., B, 2017, 154, 239-245.

21 L. Su, J. Feng, X. Zhou, C. Ren, H. Li and X. Chen, Anal. Chem., 2012, 84, 5753-5758.

22 L. Su, W. Qin, H. Zhang, Z. U. Rahman, C. Ren, S. Ma and X. Chen, Biosens. Bioelectron., 2015, 63, 384-391.

23 N. Chaibakhsh and Z. Moradi-Shoeili, Mater. Sci. Eng., C, 2019, 99, 1424-1447.

24 Y. Chen, H. Cao, W. Shi, H. Liu and Y. Huang, Chem. Commun., 2013, 49, 5013-5015.

25 F. Vetr, Z. Moradi-Shoeili and S. Özkar, Appl. Organomet. Chem., 2018, 32, e4465.

26 L. Z. Gao, J. M. Wu, S. Lyle, K. Zehr, L. L. Cao and D. Gao, J. Phys. Chem. C, 2008, 112, 17357-17361.

27 W. B. Shi, Q. L. Wang, Y. J. Long, Z. L. Cheng, S. H. Chen, H. Z. Zheng and Y. M. Huang, Chem. Commun., 2011, 47, 6695-6697.

28 X. Niu, Y. Xu, Y. Dong, L. Qi, S. Qi, H. Chen and X. Chen, J. Alloys Compd., 2014, 587, 74-81.

29 W. Wu, Q. He, H. Chen, J. Tang and L. Nie, Nanotechnology, 2007, 18, 145609.

30 L. Y. Tong, C. C. Chuang, S. Y. Wu and L. Zuo, Cancer Lett., 2015, 367, 18-25.

31 G. Y. Liou and P. Storz, Free Radical Res., 2010, 44, 479-496.

32 D. Trachootham, J. Alexandre and P. Huang, Nat. Rev. Drug Discovery, 2009, 8, 579-591.

33 T. I. Lakshmi Raj, A. U. Gurkar, A. Mandinova, S. L. Schreiber and S. W. Lee, Nature, 2011, 475, 231-234.

34 J. S. Zijian Zhou, L. Nie and X. Chen, Chem. Soc. Rev., 2016, 45, 6597-6626.

35 R. Gargallo-Caballero, L. Martin-Garcia, A. Quesada, C. Granados-Miralles, M. Foerster, L. Aballe, R. Bliem, G. S. Parkinson, P. Blaha, J. F. Marco and J. de la Figuera, J. Chem. Phys., 2016, 144, 094704.

36 H. Sun, Y. Zhou, J. Ren and X. Qu, Angew. Chem., Int. Ed., 2018, 57, 9224-9237.

37 J. Dong, L. Song, J. J. Yin, W. He, Y. Wu, N. Gu and Y. Zhang, ACS Appl. Mater. Interfaces, 2014, 6, 1959-1970.

38 B. Jiang, L. Yan, J. Zhang, M. Zhou, G. Shi, X. Tian, K. Fan, C. Hao and X. Yan, ACS Appl. Mater. Interfaces, 2019, 11(10), 9747-9755. 